\title{
Impact of corporate social responsibility on the financial performance of banks in Pakistan
}

\author{
M. Shoukat Malik ${ }^{1}$, Muhammad Nadeem ${ }^{2, *}$ \\ ${ }^{1}$ Faculty of Business Administration, Alfalah Institute of Banking and Finance, \\ Baha-ud-Din Zakariya University, Multan, Pakistan \\ ${ }^{2}$ MS Scholar, Institute of Southern Punjab, Multan, Pakistan \\ *E-mail address: muhammadnadeem19@gmail.com
}

\begin{abstract}
The purpose of this paper is to investigate the impact of Corporate Social Responsibility on the Financial Performance of banks in the service sector of Pakistan. The data is obtained from the annual reports issued by the banks during 2008-2012. To verify the relationship between EPS, ROA, ROE, Net Profit and CSR regression models are used. The results show that there is lack of CSR in Pakistan and the regression model shows that there is positive relationship between profitability (EPS, ROA, ROE, and Net Profit) and CSR practices. The Financial institutions which implements CSR in their operations earn more profit for the long term periods.
\end{abstract}

Keywords: CSR (Donation, Education, Health, Social Welfare); Banks; EPS; ROA; ROE; Net Profit

\section{INTRODUCTION}

Corporate social responsibility has become much popular in the last few years. A large number of companies issue reports on the Corporate Social Responsibility (CSR) now a days. The demand of people who affect the organizations (stakeholders) is continuously increasing for corporations to measure reports and improve their social, environmental, and economic performance.

Corporate Social Responsibility has been defined by different researchers in different ways. McWilliams and Siegel (2001) describe Corporate Social Responsibility as "Doing all those activities which are not forced by law of those countries in which they are running their business and which are not for the primary benefits of the business but for the benefits of the society."

Another researcher like Lea (2002) has defined CSR as "Corporate Social Responsibility is about all types of businesses and other organizations going beyond the legal obligations to manage the impact they have on the environment and society. In particular, this could include how organizations interact with their employees, suppliers, customers and the communities in which they operate, as well as the extent they attempt to protect the environment."

Corporate Social Responsibility has become an important part of planning to get and sustain the competitive advantage in the globally competitive companies. Kotler et al. (2005) describe that companies can gain great benefits from participating in CSR and that these 
benefits are the reasons for their engagement in Corporate Social Responsibility. Corporate Social Responsibility affects the financial performance of the firms. Financial performance means measuring and analyzing the financial objectives of the firms to see whether they are accomplished or not.

In today's global world, organization's have many challenges to operate and earn profits. People have more knowledge about the organizations, their products and services and the way organization's operate their businesses. People are more conscious about the organization's work for the prosperity of the society, the environment in which they operate and earn profits.

In the world companies are facing many problems with a new role, which is to fulfill the demands of the present generation in a socially responsible way. Organizations must take responsibility for the ways they operate in the societies and natural environment because their operations impact societies and the natural environment.

Previously studies have focused mainly on the developed countries and there is less work done on measuring the impact of Corporate Social Responsibility on Financial Performance in less developed countries like Pakistan. In less developed countries, most of the firms are not yet quite familiar with the importance of Corporate Social Responsibility and thus don't pay much attention on the Corporate Social Responsibility. Now a day's people have more knowledge about the organizations and the work they are doing for the welfare of the society. So it's important to study Corporate Social Responsibility and its impacts on the profitability of firms in these economies.

\section{LITERATURE REVIEW}

\section{1. Corporate social responsibility}

Today the corporate world is facing the concept of corporate social responsibility (CSR) wherever we see. At large corporations are encouraged to behave as socially responsible firms. However, in both the corporate and the academic world there is uncertainty as to how CSR should be defined. The beginning studies on CSR started with Bowen who issued "Social Responsibility of Business man in 1953. Many other researchers during the 60s have tried to validate and to narrate the more accurate definition of CSR (Iqbal et al, 2013). Davis (1960) states CSR as "Actions and decision made by business persons partially beyond the Organization's direct economic and technical interest". Since the 1970s, different scholars have paid more attention toward the Corporate Social Performance (CSP) as well as CSR (Carroll, 1979).

Carroll (1979) was the famous writer who intended a four part definition of CSP including the Economic Responsibility, Discretionary Responsibility, Ethical Responsibility and Legal Responsibility. Carroll (1979) argued that the managers or administrators of organizations who have selected the Corporate Social Performance must follow the criteria, the criteria from the definition of CSR that take under consideration an accurate explanation of where, why, how and in what way the owners of organization are linked to social responsibility, and a list of essentials and rules that govern the CSR. Cochran and Wood (1984) studied the different methods in which the social performance and financial performance has been put in to use in past and made up mind to use a reputation index to evaluate the CSR, they also emphasized on the demand of morality.

Hopkins, (1999) describes that the stakeholders of the firms are treated ethically or in a socially responsible manner under the concept of CSR. Stakeholders exist both within a firm 
and outside. Consequently, human development of stakeholders both within and outside the corporation is increased by behaving as a socially responsible firm.

\section{2. Determinants of Corporate Social Responsibility}

The following are the determinants of Corporate Social Responsibility.

\section{2. 1. Education}

This determinant shows that how much the Islamic and Conventional banks are paying for their employees and for other people in community who can't bear their education expenses. Education is a factor of CSR. The banks which take it under consideration, earn long term profit because such type of expenses for society build the Good-Will. Now a day's supporting for education is a key to success of financial institutions (Iqbal et al, 2013).

\section{2. 2. Health}

This determinant shows that how much the Islamic and Conventional banks are paying for the health of their employees and for the health of other people living in the community. Different amount of money is offered to hospitals for health and care of needy people of society. Employees of financial institutions enjoy the medical facility. Network can create a healthy community. Hence the financial institutions must create a network between human beings and health care (Iqbal et al, 2013).

\section{2. 3. Donation}

Donation determinant shows the interest of financial institution to pay a specific amount of money to rehabilitate the society. Financial institutions provide donations to people affected by natural disasters like flood, earthquake etc. Transferring the usufructs of someone to any other person or institution is called donation. Donation is a gift offered by a physical or a legal person, usually for the charitable purpose and for the benefit of the society. It may be in the form of cash offering, service, new or used goods like clothing, toys, food and vehicle. It also includes the emergency, relief \& development support or medical needs like donation of blood and organ's transplant. The goods and services that are offered as charity also called gift in kind. The institutions that provide gifts called the donor and individual or any institution who accepts the gift called the done (Iqbal et al, 2013).

\section{3. Financial Performance}

Financial Performance can be defined as it measures the financial position of a company over a specified time period to know how efficiently a company is using its resources to generate income. Return on asset, return on equity, net profit, earning per share etc are evaluated to measure firm's financial health.

\section{4. Measures of Financial Performance}

Following are some measures of profitability of the firms.

\section{4. 1. Earning per Share}

Earnings per Share show the earning of banks that how much profit is earned during the period of one year on behalf of each outstanding share of common stock. 


\subsubsection{Return on Asset}

Return on Assets often called the Return on Investment (ROI). Return on Assets shows the profit generated by the assets of banks annually. Return on assets is an indicator that how much an organization is earning over its total assets.

\section{4. 3. Return on Equity}

Return on Equity measures the return earned on both preferred and common stockholders' investment in the financial institution annually. It shows the ability of generating profits from every unit of shareholders' equity.

\section{4. 4. Net profit}

Net profit means revenues minus all expenses. Net profit of the organization is shown after deducting the interest expenses and taxes on the profit.

Miles and Munilla (2005) describe the motives for participating in CSR by using Carroll's (1991) Pyramid of Corporate Social Responsibility, which illustrates how different levels of commitment to CSR are related to motives and outcomes. Carroll (1991) describes that a company's CSR philosophy can be, compliance driven, profit driven, driven by caring, synergetic or holistic. In the first stage of CSR category, which is called the legal stage, companies engage in CSR as it is their duty and obligation to follow laws and regulations. In the economic stage, companies use CSR as a strategy to create a competitive advantage and gain improved financial performance. The ethical and philanthropic stage has the aim to have a balance between the profit, people and the planet. In this stage the company does not only focus on profit but also on social welfare.

Several authors argue that companies can gain enormous benefits by being socially responsible (Idowu \& Papasolomou, 2007). There are a large number of different views of why companies engage in CSR and what benefits a company actually gets from participating in CSR. Companies participate in CSR in order to look better, feel better, do better and live longer. They explain that by participating in CSR the company will look good in the view of potential customers, business colleagues, investors and in the media etcetera. Furthermore, employees, customers, stockholders and board members will actually feel good. Many researchers also argue that CSR improve the brand, and some claim that companies with a strong reputation for CSR will last longer. Kotler et al. (2005) describe that companies can gain great benefits from participating in CSR and that these benefits are the reasons for their engagement in CSR. Kramer and Porter (2006) describe the reasons for participating in CSR by moral obligation, sustainability, license to operate and reputation.

McGuire et al. (1988) have in conformity with Sarbutts (2003) established that there are various arguments what the relationship between a company's CSR engagement and their financial performance is. Sarbutts (2003) argues that if CSR affect a company's reputation, it is also very likely that this will affect the company's financial performance. Balabanis et al. (1998) continue this by arguing that companies engage in CSR due to enlightened self-interest since CSR is believed to enhance corporate image and thereby improve financial performance. However, he also points out that all researchers do not share this point of view. This is mainly due to the fact that there are diverse results from previous research on how investing in CSR affect a company's performance.

McGuire et al. (1988) have on the basis of previous research been able to sort the relationship between CSR usage and financial performance into three main viewpoints. In the first viewpoint, it is argued that CSR investments put these companies into an economic 
disadvantage compared to less responsible companies. The second viewpoint is that explicit CSR investment costs are minimal and that companies investing in CSR actually gain benefits from this in terms of employee morale and productivity. In the third viewpoint, costs from CSR investments are significant; they are however offset by the reduction in other company costs. It is also suggested that companies should satisfy all stakeholders not just the shareholders of a company. Most of the scholars investigating corporate social responsibility and financial performance have argued for a positive association. Several authors have cited improved employee and customer goodwill as an important outcome of social responsibility (Davis, (1973); Soloman \& Hansen, (1985)). For example, a firm perceived as high in social responsibility may face relatively few labor problems, and customers may be favorably disposed to its products. Socially responsible activities may also improve a firm's standing with such important constituencies as bankers, investors, and government officials. Improved relationships with these constituencies may bring economic benefits. Indeed, banks and other institutional investors have reported social considerations to be a factor in their investment decisions (Spicer, 1978).

\section{Development of Hypothesis}

On the basis of above literature review, these hypothesis may be developed:

H1: There is positive and significant relationship between CSR and ROA.

H2: There is positive and significant relationship between CSR and ROE.

H3: There is positive and significant relationship between CSR and Net Profit.

H4: There is positive and significant relationship between CSR and EPS.

H5: There is positive and significant relationship between CSR and financial performance.

\section{Conceptual framework}

Based on the above-mentioned literature review, the following theoretical model framework has been developed.

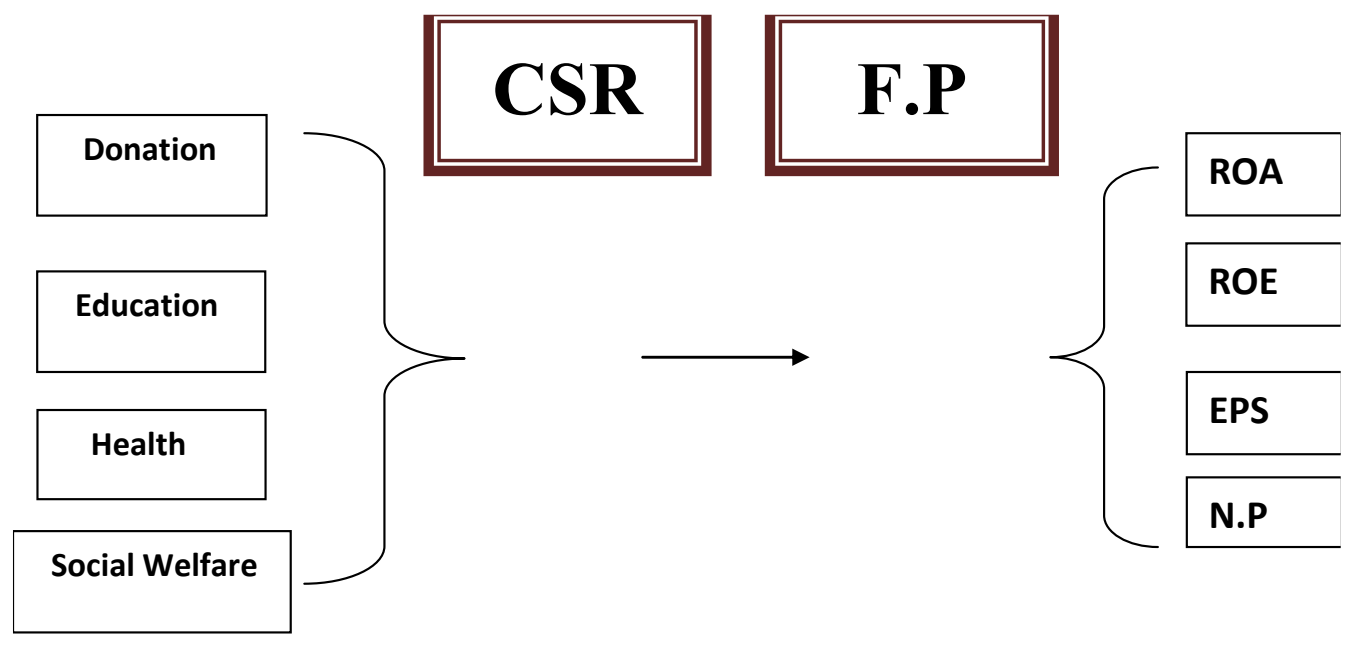

\section{METHODOLOGY}

The population for this study is Pakistani and multinational banks from banking sector operating in Pakistan. 
Sample size for this study is eight banks. The study is conducted on the basis of secondary data. For the purpose of data collection annual reports are used. The study is quantitative in nature as the results and final findings are based on data collection from annual reports.

And these results are quantified using different statistical tools. This study is related to panel data in nature. Data from annual reports is collected and is used to generate information with the help of statistical tools and the analysis is done.

\section{RESULT AND DISCUSSION}

\section{1. Corporate Social Responsibility and Return on Asset}

H1: There is positive and significant relationship between CSR and ROA. The Results for the $\mathrm{H} 1$ are given below for regression analysis:

Table 1. Regression Analysis.

\begin{tabular}{|cc|c|c|c|c|c|}
\hline \multirow{2}{*}{ Model } & \multicolumn{2}{|c|}{$\begin{array}{c}\text { Unstandardized } \\
\text { Coefficients }\end{array}$} & $\begin{array}{c}\text { Standardized } \\
\text { Coefficients }\end{array}$ & \multirow{2}{*}{$\mathrm{t}$} & \multirow{2}{*}{ Sig. } \\
\cline { 2 - 5 } & $\mathrm{B}$ & Std. Error & Beta & & \\
\hline \multirow{2}{*}{1} & (Constant) & 13.934 & 3.754 & & 3.711 & .034 \\
& CSR & .003 & .003 & .471 & .924 & .424 \\
\hline
\end{tabular}

a. Dependent Variable: ROA

The regression analysis performed for testing the effect of CSR on return on asset in the banking sector is shown in above table.

The value of $\beta$ is 0.471 (Which is positive), T-Value is .924 (which is less than standard 2.00 ) and P-value or significance level is .424 (Which is greater than 0.05). Results illustrate that there is positive relationship between CSR and ROA.

It means when the banks in Pakistan increases their spending on CSR the return on assets of the banks will also increase.

Because of this positive relationship between CSR and ROA, companies will spend more on CSR especially in the developing countries.

\section{2. Corporate Social Responsibility and Return on Equity}

H2: There is positive and significant relationship between CSR and ROE.

The Results for the $\mathrm{H} 2$ are given below for regression analysis: 
Table 2. Regression Analysis.

\begin{tabular}{|c|c|c|c|c|c|c|}
\hline \multicolumn{7}{|c|}{ Model Summary } \\
\hline & \multirow[t]{2}{*}{ Model } & \multicolumn{2}{|c|}{$\begin{array}{c}\text { Unstandardized } \\
\text { Coefficients }\end{array}$} & \multirow{2}{*}{$\begin{array}{c}\text { Standardized } \\
\text { Coefficients } \\
\text { Beta }\end{array}$} & \multirow[t]{2}{*}{$\mathrm{T}$} & \multirow[t]{2}{*}{ Sig. } \\
\hline & & B & Std. Error & & & \\
\hline \multirow{2}{*}{1} & (Constant) & 95.024 & 8.555 & & 11.108 & .002 \\
\hline & CSR & .010 & .007 & .665 & 1.543 & .221 \\
\hline
\end{tabular}

a. Dependent Variable: ROE

The regression analysis performed for testing the effect of CSR on ROE in the banking sector is shown in above table. The value of $\beta$ is .665 (Which is positive), T-Value is 1.543 (which is less than standard 2.00) and P-value or significance level is .221 (Which is greater than 0.05). This table shows the regression results that reveal the fact that Corporate Social Responsibility has Positive relationship with return on equity. CSR includes donation, spending of banks on education of employees and people living in society, amounts given for the better health of employees and other people of community, social welfare. Preferred and Common shareholder's return will increase by spending on CSR which will decrease the difficulties of management. This positive relation between CSR and ROE will motivate other companies to invest on CSR.

\section{3. Corporate Social Responsibility and Net Profit}

H3: There is positive and significant relationship between CSR and net profit.

The Results for the H3 are given below for regression analysis:

Table 3. Regression Analysis.

\begin{tabular}{|c|c|c|c|c|c|c|}
\hline \multicolumn{7}{|c|}{ Model Summary } \\
\hline & \multirow[t]{2}{*}{ Model } & \multicolumn{2}{|c|}{$\begin{array}{c}\text { Unstandardized } \\
\text { Coefficients }\end{array}$} & $\begin{array}{l}\text { Standardized } \\
\text { Coefficients }\end{array}$ & \multirow[t]{2}{*}{$\mathrm{T}$} & \multirow[t]{2}{*}{ Sig. } \\
\hline & & B & Std. Error & Beta & & \\
\hline \multirow{2}{*}{1} & (Constant) & 23943.811 & 6130.964 & & 3.905 & .030 \\
\hline & CSR & .972 & 4.830 & .115 & .201 & .853 \\
\hline
\end{tabular}

a. Dependent Variable: Net profit

The regression analysis performed for testing the effect of CSR on net profit in the banking sector is shown in above table. The value of $\beta$ is .115 (Which is positive), T-Value is .201 (which is less than standard 2.00) and P-value or significance level is .853 (Which is greater than 0.05). Results describe that there is positive relationship of CSR with net profit in the banking sector of Pakistan. It shows that stakeholders are getting benefits by giving funds for CSR because the profit of the banks is increasing with the increase in CSR. Performance of the management is measured through net profit. Management will increase donations because 
of positive relationship between donation and net profit. CSR relation with net profit is positive that explain its positive impact on the net profit.

\section{4. Corporate Social Responsibility and Earning Share}

H4: There is positive and significant relationship between CSR and EPS.

The Results for the H4 are given below for regression analysis:

Table 4. Regression Analysis.

\begin{tabular}{|c|c|c|c|c|c|c|}
\hline \multicolumn{7}{|c|}{ Model Summary } \\
\hline \multirow{2}{*}{\multicolumn{2}{|c|}{ Model }} & \multicolumn{2}{|c|}{$\begin{array}{c}\text { Unstandardized } \\
\text { Coefficients }\end{array}$} & \multirow{2}{*}{$\begin{array}{c}\begin{array}{c}\text { Standardized } \\
\text { Coefficients }\end{array} \\
\text { Beta }\end{array}$} & \multirow[t]{2}{*}{$\mathrm{t}$} & \multirow{2}{*}{ Sig. } \\
\hline & & B & Std. Error & & & \\
\hline \multirow{2}{*}{1} & (Constant) & 38.099 & 2.310 & & 16.497 & .000 \\
\hline & CSR & .002 & .002 & .548 & 1.135 & .339 \\
\hline
\end{tabular}

a. Dependent Variable: EPS

The regression analysis performed for testing the effect of CSR on earning per share in the banking sector is shown in above table. The value of $\beta$ is .548 (Which is positive), T-Value is 1.135 (which is less than standard 2.00) and P-value or significance level is .339 (Which is greater than 0.05). Results describe that there is positive relationship of CSR on earning per share.

It shows that common shareholder's earnings are increasing with the increase in the amount of funds given by the banks for CSR. Common shareholders are the real owners of the companies and their earning per share is increasing with the funds given as CSR which will encourage them to give donations. CSR relation with Earning per Share is positive that explain its positive impact on the Earning per Share.

\section{5. Corporate Social Responsibility and Financial Performance}

H5: There is positive and significant relationship between CSR and FP. The Results for the H5 are given below for regression analysis:

Table 5. Regression Analysis.

\begin{tabular}{|c|c|c|c|c|c|c|}
\hline \multicolumn{7}{|c|}{ Model Summary } \\
\hline \multirow{2}{*}{\multicolumn{2}{|c|}{ Model }} & \multicolumn{2}{|c|}{$\begin{array}{c}\text { Unstandardized } \\
\text { Coefficients }\end{array}$} & \multirow{2}{*}{$\begin{array}{c}\text { Standardized } \\
\text { Coefficients } \\
\text { Beta }\end{array}$} & \multirow[t]{2}{*}{$\mathrm{t}$} & \multirow[t]{2}{*}{ Sig. } \\
\hline & & B & Std. Error & & & \\
\hline \multirow{2}{*}{1} & (Constant) & 24019.601 & 6128.843 & & 3.919 & .030 \\
\hline & CSR & .964 & 4.828 & .115 & .200 & .854 \\
\hline
\end{tabular}

a. Dependent Variable: FP 
The regression analysis performed for testing the effect of CSR and FP in the banking sector is shown in above table. The value of $\beta$ is .115 (Which is positive), T-Value is .200 (which is less than standard 2.00) and P-value or significance level is .854 (Which is greater than 0.05). Results describe that there is positive relationship of Corporate Social Responsibility and financial performance. Overall the financial performance of the banks is increasing by spending on corporate social responsibility in Pakistan. Return on asset, return on equity, net profit and earnings per share all have positive relation with CSR and all are increasing with the increase in the spending of CSR.

Discussion directs that CSR affect the financial performance of banks in Pakistan. Companies use CSR as a strategy to create a competitive advantage and gain improved financial performance. Companies in the developed countries are considering CSR as their strategic planning and gaining long term benefits. Companies and other stakeholders in the developed nations have information regarding CSR but in the less developed countries like Pakistan companies and other stakeholders are not much aware about the concept of CSR and its benefits.

The findings of this study show that there is positive and insignificant relationship between Corporate Social Responsibility and the Financial Performance which demonstrates that there is positive impact of Corporate Social Responsibility on the Financial Performance of banks in Pakistan. This positive relationship between Corporate Social Responsibility and the Financial Performance reveals social behavior of Pakistani banks.

Pakistani banks are contributing as much as they can contribute in the social well being of society, improving the living standards by promoting education and better health facilities, protecting environment from hazardous changes. They are taking good care of their employees and stakeholders in order to build their trust and confidence. On the other hand people of developing countries like Pakistan are not much aware about the concept of CSR. They don't have information about the firm's contribution for the well being of society and environment.

Managers can communicate the unique benefits of CSR and differentiate their firms and create a good and positive image. It is also important in Pakistan where companies are not using CSR as strategic planning they can use it and reduce promotion cost. Organizations in the developed nations portray themselves as socially responsible firms and enjoy its positive financial affects. These firms spend for the well being of the societies, for improving living standard of employees, for education and health care of employees, for the better environment etc. People of developed economies also have information about the firm's activities and stakeholders put pressure on the firms to act as socially responsible firms.

\section{RECOMMENDATIONS}

Based on what is shown and discussed above, it can be argued that banks should fulfill their social responsibilities then it will improve the society, environmental conditions and overall economy of Pakistan which leads to create positive image of banks and all other stakeholders' regarding the organizations.

Banks may portray themselves as socially responsible firms it will lead to improve the overall financial performance of the Banks. Government should play its role to motivate the banks to spend for the welfare of the societies, nations, environment where they operate their businesses and earn profits. 


\section{LIMITATIONS AND FUTURE RESEARCH DIRECTIONS}

The focus of this study is only on service sector of Pakistan specifically banks. Further research can be done in other sectors like telecom, automobiles etc. The findings of this study are based on limited data for a limited period of time. Future studies should use data with a longer period to obtain a more valid measurement results. We planned to take maximum number of banks but non availability of data restricted us to work with sample of eight banks. It is recommended to multiply the number of samples. Disclosure of CSR is voluntary so there is no standard rule of the regulator which can be used as reference to measure Corporate Social Responsibility. Complete data relevant to the components of Corporate Social Responsibility was not available and most of the banks were having negative earnings. There exists less work on Corporate Social Responsibility in Pakistan and other developing countries so it should be further explored in developing countries and Pakistan as well. Future studies are expected to connect Corporate Social Responsibility to the value of the company.

\section{References}

[1] Balabanis, G., Phillips, H. C., \& Lyall, J. (1998). Corporate social responsibility and economic performance in the top British companies: are they linked?.European Business Review, 98(1), 25-44.

[2] Carroll, A. B. (1979). A three dimensional model of corporate performance. Academy Of Management Review, 4, 497-505.

[3] Carroll, A. B. (1991). The pyramid of corporate social responsibility: toward the moral management of organizational stakeholders. Business Horizons, 34(4), 39-48.

[4] Cochran, P. L., \& Wood, R. A. (1984). Corporate social responsibility and financial performance. Academy Of Management Journal, 27(1), 42-56.

[5] Davis, K. (1960). Can business afford to ignore social responsibilities? California Management Review, 2, 70-76.

[6] Davis, K. (1973). The case for and against business assumption of social responsibilities. Academy of Management Journal, 16(2), 312-322.

[7] Hopkins, M. (1999). The Planetary Bargain: Corporate Social Responsibility Comes Of Age. New York: Macmillan.

[8] Idowu, S. O., \& Papasolomou, I. (2007). Are the corporate social responsibility matters based on good intentions or false pretences? An empirical study of the motivations behind the issuing of CSR reports by UK companies. Corporate Governance, 7(2), 136-147.

[9] Iqbal, N., Ahmad, N., \& Kanwal, M. (2013). Impact of Corporate Social Responsibility on Profitability of Islamic and Conventional Financial Institutions. Applied mathematics in Engineering, Management and Technology 1(2), 26-37.

[10] Kotler, P., \& Lee, N. (2005). Corporate Social Responsibility: Doing the Most Good For Your Company and Your Cause. Wiley. com.

[11] Kramer, M. R., \& Porter, M. E. (2006). Strategy and society: the link between competitive advantage and corporate social responsibility. Harvard Business Review. 
[12] Lea, R.(2002). Corporate social responsibility: IOD member opinion survey. The Institute Of Directors, UK, 10.

[13] McGuire, J. B., Sundgren, A., \& Schneeweis, T. (1988). Corporate social responsibility and firm financial performance. Academy Of Management Journal, 31(4), 854-872.

[14] McWilliams, A., \& Siegel, D. (2001). Corporate social responsibility and financial performance: correlation or misspecification?. Strategic Management Journal, 21(5), 603-609.

[15] Miles, L. S., \& Munilla, M. P. (2005). The corporate social responsibility continuum as a component of stakeholder theory. Business and Society Review, 110(4), 371-387.

[16] Sarbutts, N. (2003). Can SMEs “do" CSR? A practitioner's view of the ways small-and medium-sized enterprises are able to manage reputation through corporate social responsibility. Journal of Communication Management, 7(4), 340-347.

[17] Soloman, R., \& Hansen, K. (1985). It's Good Business (Atheneum, New York).

[18] Spicer, B. H. (1978). Investors, corporate social performance and information disclosure: An empirical study. Accounting Review, 94-111.

[19] Nadeem Iqbal, Naveed Ahmad, Zeeshan Haider, Sonia Anwar. Impact of foreign direct investment (FDI) on GDP: A Case study from Pakistan. International Letters of Social and Humanistic Sciences 5 (2014) 73-80. 